\title{
Addition to the desmid flora (Charophyta: Desmidiales) of Nizhnevartovsk district, KMAO-Yugra, Russia
}

\section{Дополнение к флоре десмидиевых водорослей (Charophyta: Desmidiales) Нижневартовского района ХМАО-Югры, Россия}

\author{
Shakhmatov A. S. \\ Шахматов А. С. \\ Ural Federal University, Ekaterinburg, Russia.E-mail: shahmatov1992@mail.ru \\ Уральский Федеральный Университет, г. Екатеринбург, Россия
}

\begin{abstract}
Summary. Five species of desmid algae new to Nizhnevartovsk city are reported. Three species (Closterium abruptum, Cl. jenneri, Euastrum ansatum) are rare for Nizhnevartovsk administrative region, one (Penium margaritaceum) is new for Khanty-Mansi Autonomous Okrug - Yugra.
\end{abstract}

Key words. Closteriaceae, Desmidiaceae, new records, rare species, Peniaceae, West Siberia.

Peфepam. Приведена информация о находке пяти видов десмидиевых водорослей в городе Нижневартовске. Три из них (Closterium abruptum, Cl. jenneri, Euastrum ansatum) являются редкими для Нижневартовского административного района, один вид (Penium margaritaceum) - новый для Ханты-Мансийского Автономного Округа Югры.

Ключевые слова. Западная Сибирь, новые находки, редкие виды, Closteriaceae, Desmidiaceae, Peniaceae.

Introduction. Nizhnevartovsk administrative district, with an area of $117,300 \mathrm{~km}^{2}$, is the largest part of Khanty-Mansi Autonomous Okrug - Yugra (KMAO - Yugra). The district is located in the middle of taiga zone, in the eastern part of the West Siberian Plain. A large number of lakes, marshes and rivers, including a part of the middle course of the Ob River are situated on its territory.

Biodiversity studies of Desmids, both special and general algofloristic studies, are carried out mainly on large rivers such as Ob, Vakh, Sarmsabun and Seikryogan, as well as in vicinities of large settlements and in the Nature Park "Sibirskiye uvaly" (Naumenko, 1992, 1996, 2006, 2007; Safonova, Shaulo, 2006, 2007; Skorobogatova, Naumenko, 2009; Naumenko, Ptukhina, 2013; Naumenko, Gidora, 2014; Naumenko, Gidora, 2017; Skorobogatova, 2018). According to the available literature data, the algal flora of the region is quite rich, and it is noteworthy that representatives of order Desmidiales (Closteriaceae family in particular) often dominate in the number of species over other groups of algae.

Here we report records of new for the region and rare desmid species made in Lake Komsomolskoye in Nizhnevartovsk city, which supplement the floristic lists of Nizhnevartovsk district and KMAO-Yugra in general, as well as expanding the geographical distribution of individual species on that territories.

Materials and Methods. The present study was carried out during the middle of September 2014 in Nizhnevartovsk city, which is situated in the south-western part of Nizhnevartovsk administrative district, on the right bank of the Ob River (Fig. 1A, B). The city is surrounded by middle taiga forests with Pinus sylvestris L. and P. sibirica Du Tour as dominants. The climate of this area is continental, with moderately cold winter (average temperature in January varies from $-22^{\circ} \mathrm{C}$ to $-24^{\circ} \mathrm{C}$ ) and relatively warm summer (average temperature in July varies from $16^{\circ} \mathrm{C}$ to $17^{\circ} \mathrm{C}$ ).

The samples of plankton and benthos were taken from Lake Komsomolskoye (N60 57'01.6", E76 $\left.34^{\prime} 37.2^{\prime \prime}\right)$ on its both sandy and swampy banks. Until a recent time, this water body was heavily contaminated with oil products, but at present, it is almost completely cleared of pollution. 

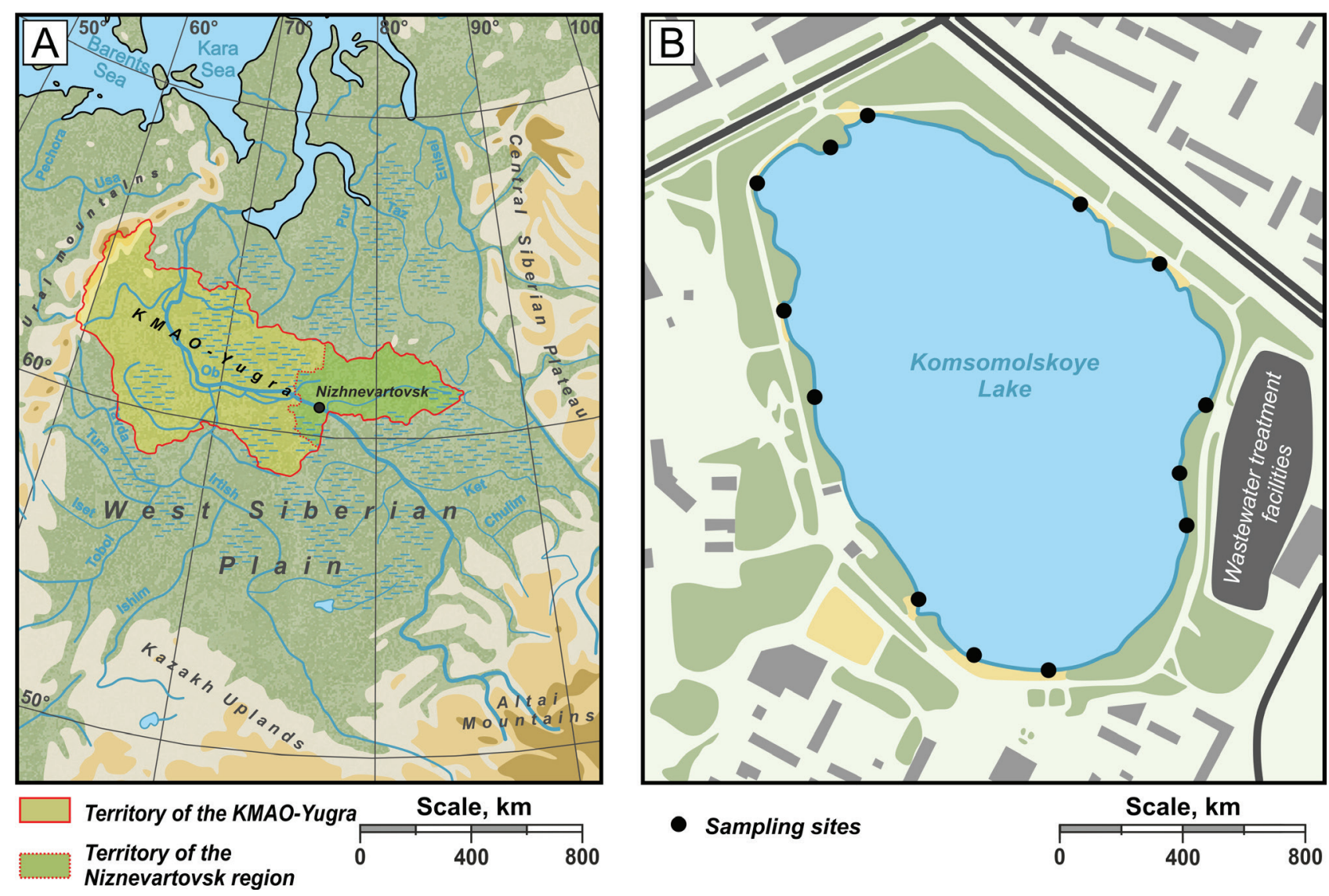

Fig. 1. The location of Nizhnevartovsk administrative district in the West Siberian Plain (A) and Komsomolskoye Lake in Nizhnevartovsk city (B).

The study of the collected material was carried out by using light microscopes Levenhuk 320 and Levenhuk C310 NG digital camera. Cell measurements were made using ToupView v.3.7.1047 software. Species identification was performed by using a special literature (West, West, 1904; Kosinskaya, 1960; Palamar-Mordvintseva, 1982; Coesel, Meesters, 2007). The validity of taxa was verified with Algaebase (Guiry, Guiry, 2019).

List of Species. As a result of the collected material study, the following annotated list was compiled. For each taxon the abundance estimation ( $\mathrm{Ab} . \mathrm{s}$ - single finding, $\mathrm{r}$ - rare, $\mathrm{c}$ - common, $\mathrm{a}$ - abundant, $\mathrm{m}$ - mass occurrence), dimensions (Dim.), information about distribution in KMAO - Yugra territory (Distr.) and illustrations are given.

\section{Familia Peniaceae Haeckel, 1894}

Penium margaritaceum Brébisson in Ralfs, 1848 (Fig. 2, 1) - Ab.: " $\mathrm{r}$ " in plankton samples. Dim.: 107.7-118.3 $\mu \mathrm{m}$ long and 22.8-23.9 $\mu \mathrm{m}$ wide. Descr.: cells cylindrical, with light median constriction and broadly rounded ends. Cell wall slightly brownish or colorless, with griddle bands and longitudinal rows of small granules. Distr.: this species has a worldwide distribution, but it was recorded in KMAO - Yugra territory for the first time. In addition, this species is common in the nearest regions such as Polar Urals (Patova and Demina, 2007; Briškaite et al., 2016) and South-East part of West Siberian Plain (Kosinskaya, 1960).

Familia Closteriaceae Bessey, 1907

Penium margaritaceum Brébisson in Ralfs, 1848 (Fig. 2, 1) - Ab.: " $\mathrm{r}$ " in plankton samples. Dim.: 107.7-118.3 $\mu \mathrm{m}$ long and 22.8-23.9 $\mu \mathrm{m}$ wide. Descr.: cells cylindrical, with light median constriction and 
broadly rounded ends. Cell wall slightly brownish or colorless, with griddle bands and longitudinal rows of small granules. Distr.: this species has a worldwide distribution, but it was recorded in KMAO - Yugra territory for the first time. In addition, this species is common in the nearest regions such as Polar Urals (Patova and Demina, 2007; Briškaitė et al., 2016) and South-East part of West Siberian Plain (Kosinskaya, 1960).
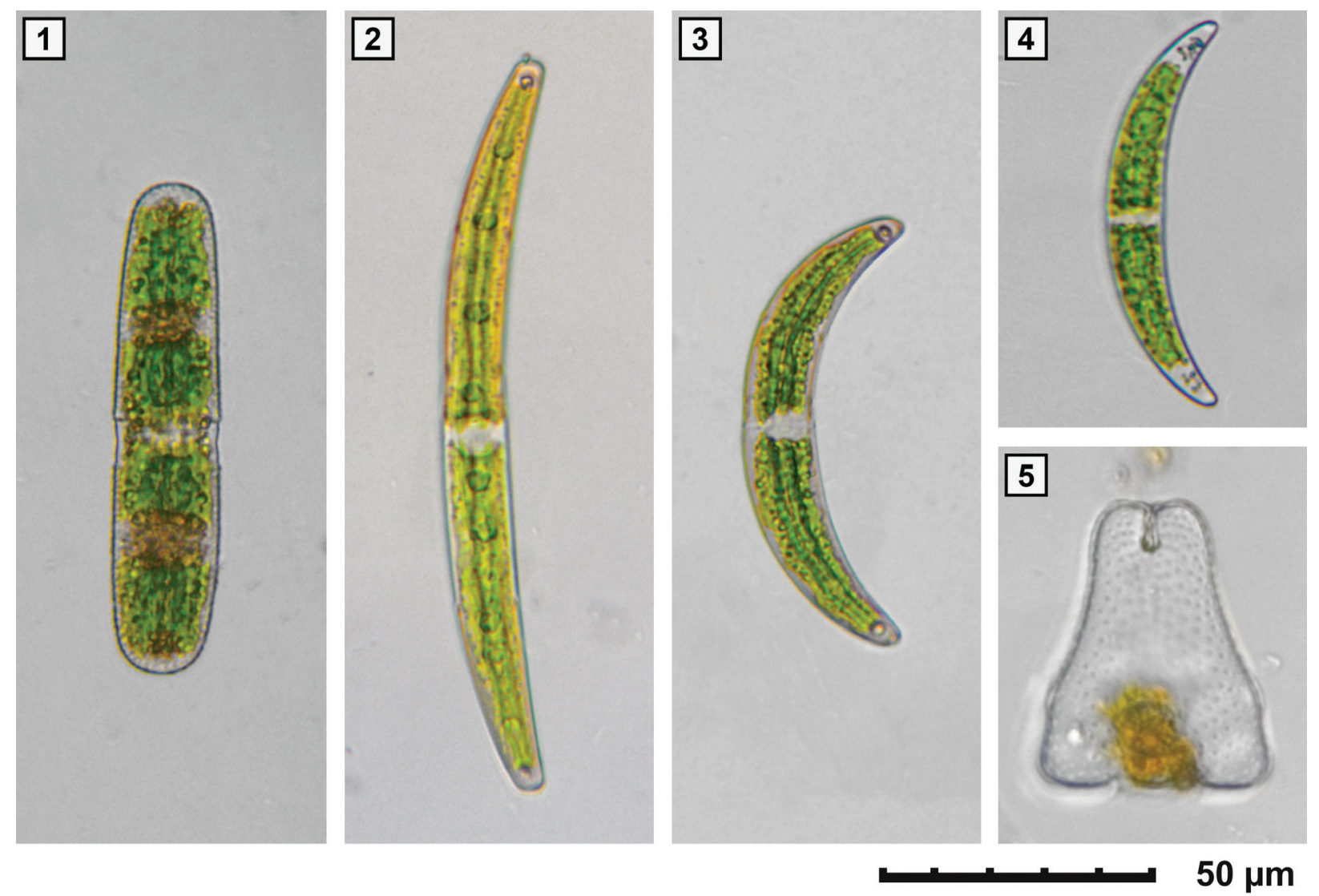

Fig. 2. Desmids, recorded in Komsomolskoye Lake: 1 - Penium margaritaceum, 2 - Closterium abruptum, 3 - Cl. jenneri, $4-C l$. venus, 5 - Euastrum ansatum empty semicell.

\section{Familia Closteriaceae Bessey, 1907}

Closterium abruptum West, 1892 (Fig. 2, 2) - Ab.: "r" in plankton samples. Dim.: 151.5-161.6 $\mu \mathrm{m}$ long and 15.1-15.9 $\mu \mathrm{m}$ wide. Ends $6.8-7.1 \mu \mathrm{m}$ wide. Descr.: cells slightly curved, with obviously indistinctive striated brown-colored cell wall and truncate ends. Terminal vacuoles contain one large crystal. Distr.: species is new to Nizhnevartovsk district and rare to KMAO - Yugra, where it is recorded in Middle and lower course of the Ob River (Naumenko, 1992).

Closterium jenneri Ralfs, 1848 (Fig. 2, 3) - Ab.: "s" in plankton samples. Dim.: $112.3 \mu \mathrm{m}$ long and $16.5 \mu \mathrm{m}$ wide. Ends $7 \mu \mathrm{m}$ wide. Descr.: cells moderately curved, with slightly striate colorless cell wall and acuminate ends. Terminal vacuoles contain one large small crystal. Distr.: this species is rare for Nizhnevartovsk district and KMAO - Yugra, where it is known from Sarmsabun (Naumenko, Gidora, 2014), Seikryogan (Naumenko, 2007) and Vakh (Skorobogatova, 2018) rivers only.

Closterium venus Kützing ex Ralfs, 1848 (Fig. 2, 4) - Ab.: "c" in plankton samples. Dim.: 89.1-91.5 $\mu \mathrm{m}$ long and 12.8-13.4 $\mu \mathrm{m}$ wide. Ends 3.2-4 $\mu \mathrm{m}$ wide. Descr.: cells moderate curved, with smooth colorless cell wall and rounded ends. Terminal vacuoles contain several small crystals. Distr.: species is widespread on Nizhnevartovsk district territory, it recorded in Seykoryogan (Naumenko, 2007), Sarmsabun (Naumenko and Gidora, 2014) and Vakh (Skorobogatova, 2018) rivers, as well as from the vicinity of the Vysokiy village (Safonova \& Shaulo, 2007). 


\section{Familia Desmidiaceae Ralfs, 1848}

Euastrum ansatum Ehrenberg ex Ralfs, 1848 (Fig. 2, 5) - Ab.: "s" in benthos samples. Dim.: $51.1 \mu \mathrm{m}$ wide and presumably $122.9 \mu \mathrm{m}$ long. Polar lobe $25.2 \mu \mathrm{m}$ wide. Isthmus $\sim 17.4 \mu \mathrm{m}$ wide. The record of only one empty semicell of this species makes it possible only to assume a length of the living cell and isthmus width. Descr: Semicells are pyramidal in shape, with rudimental lateral and well-developed basal lobes. Polar lobe with closed deep median incision. Cell wall smooth. Distr.: this species is new to Nizhnevartovsk district and rare to KMAO - Yugra, where it is recorded in swamps near Yugorsk City (Shakhmatov, Pavlovskiy, 2019). In addition, this species is recorded from the neighboring regions such as Yamal Peninsula (Luknitskaya, 2001) and Polar Urals (Briškaite et al., 2016).

Discussion. Summarizing the above, during the determination of the material collected in Lake Komsomolskoye in Nizhnevartovsk city, only five species of desmid algae belonging to families Peniaceae, Closteriaceae and Desmidiaceae have been found. One of them, Closterium venus, which characterized by a high abundance in samples, is widespread both on Nizhnevartovsk administrative region territory and in the territory of Khanty-Mansi Autonomous Okrug - Yugra. This record expands the geographical distribution of this species in the region. Another species, Closterium jenneri, was previously recorded only several times in the Nizhnevartovsk region, which indicates its relative rarity. Two species (Closterium abruptum and Euastrum ansatum) were previously found in other parts of Khanty-Mansi Autonomous Okrug - Yugra, but for Nizhnevartovsk region they are recorded for the first time. The last species, Penium margaritaceum, is new to the territory of Khanty-Mansi Autonomous Okrug - Yugra.

It should be noted that most of the above-mentioned species are characterized by a single or rare occurrence in samples, which can be explained by the recent purification of the lake, during which its biota was greatly transformed, which led to the emergence of suitable conditions for desmids in it. Thus, it is most likely that these species were accidentally introduced into the lake from nearby wetlands.

The fact that the recorded species, which are quite common in the neighboring regions, are rare or new for Nizhnevartovsk district and for Khanty-Mansi Autonomous Okrug - Yugra in general, clearly indicates the necessity of further floristic study of the algoflora.

\section{REFERENCES}

Briškaité R., Patova E., Juzénas S. Desmid flora in the lakes of the Khrebtovyi Nature Reserve in the Polar Ural (Russia) // Botanica Lithuanica, 2016. - Vol. 22, № 2. - P. 113-122.

Coesel P. F. M., Meesters K. J. Desmids of the lowlands. - KNNW Publishing - Zeist, 2007. - 351 p.

Guiry M. D. Guiry G. M. 1996-2019. AlgaeBase. World-wide electronic publication. - National University of Ireland, Galway. URL: http://www.algaebase.org (Accessed at 12 December 2019).

Kosinskaya E. K. Flora sporovykh rastenii SSSR. Conjugaty. Desmidievye Vodorosli 5(2). - Moscow-Leningrad: USSR Academy of Sciences Publishing House, 1960. - 706 p. (In Russian) (Косинская Е. К. Флора споровых растений СССР. Коньюгаты или сцеплянки. Десмидиевые водоросли 5(2). - Москва-Ленинград: Издательство АН СССР, 1960. - 706 c.)

Luknitskaya A. F. Chlorophyta (Conjugatae) aquatorium nonnullarum in parte australi paeninsulae Jamal // Novosti Sistematiki Nizshikh Rastenii, 2001. - Vol. 34. - P. 30-34. (In Russian) (Лукницкая А. Ф. Зеленые водоросли (конъюгаты) некоторых водоемов южной части полуострова Ямал // Новости сист. низ. раст., 2001. - Т. 34. - С. 23-26.)

Naumenko Y. V. Species composition of desmids (Desmidiales, Chlorophyta) of the Ob River. - Bot. Zhurn. (Moscow \& St. Petersburg), 1992. - Vol. 77, №11. - P. 89-93. (In Russian) (Науменко Ю. В. Видовой состав десмидиевых (Desmidiales, Chlorophyta) водорослей реки Оби - Бот. журн. (Москва и Санкт-Петербург), 1992. - Т. 77. №11. C. 89-93.)

Naumenko Y. V. Ad floram Desmidialium fluminis Ob // Novosti Sistematiki Nizshikh Rastenii, 1996. - Vol. 31. P. 43-45. (In Russian) (Науменко Ю. В. К флоре десмидиевых водорослей реки Обь // Новости сист. низ. раст., 1996. - T. 31. - C. 43-45.)

Naumenko Y. V. Algoflora of "Sibirskie Uvaly" Nature Reserve // Biological Resources and Nature Management: collection of scientific works. - Defis-Surgut, 2006. - Vol. 9. - P. 159-175. (In Russian) (Науменко Ю. В. К изучению 
альгофлоры природного парка «Сибирские увалы» // Биологические ресурсы и природопользование. Сборник научных трудов. - Вып. 9. - Сургут: Дефис, 2006. - С. 157-175.)

Naumenko Y. V. First data on algae of "Sibirskiye Uvaly" nature park (West Siberia, Russia) // Algologia, 2007. - Vol. 17, № 2. - Р. 230-236. (In Russian) (Науменко Ю. В. Первые сведения о водорослях природного парка «Сибирские Увалы» (Западная Сибирь, Россия) // Альгология, 2007. - Т. 17, № 2. - С. 230-236.)

Naumenko Y. V., Gidora O. Y. Species diversity of algae r. Sarm-Sabun (Western Siberia) // Proceedings of Voronezh State University. Series: Chemistry. Biology. Pharmacy, 2014. - Vol. 2 - Р. 76-85. (In Russian) (Науменко Ю. В., Гидора О. Ю. Видовое разнообразие водорослей р. Сарм-Сабун (Западная Сибирь) // Вестник ВоронежскогоГУ. Серия: Химия. Биология. Фармация, 2014. - № 2 - С. 76-85.)

Naumenko Y. V., Gidora O. Y. Micrasterias C. Agarth ex Ralfs species in the natural park "Sibirskiye Uvaly" (West Siberia, Russia) // Ukrainian Journal of Ecology, 2017. - Vol. 7, № 2. - 116-119. (In Russian) (Науменко Ю. В., Гидора О. Ю. Виды рода Micrasterias C. Agardh ex Ralfs природного парка «Сибирские Увалы» (Западная Сибирь, Россия) // Ukrainian Journal of Ecology, 2017 - Vol. 7, № 2. - 116-119.)

Naumenko Y. V., Ptukhina O. Y. Desmids algae (Desmidiales) of the natural park «Sibirskie Uvaly», West Siberia, Russia // Turczaninowia, 2013. - Vol. 16, № 2. - P. 81-83. (In Russian) (Науменко Ю. В., Птухина О. Ю. Десмидиевые водоросли (Desmidiales) природного парка «Сибирские Увалы», Западная Сибирь, Россия // Turczaninowia, 2013. - Т. 16, № 2. - C. 81-83.)

Palamar-Mordvintseva G. M. Opredelitel presnovodnykh vodoroslei SSSR. Conjugaty. Poryadok Desmidievye. 11(2). - Leningrad: Nauka, 1982. - 620 p. (In Russian) (Паламарь-Мордвинцева Г. М. Определитель пресноводных водорослей СССР. Вып. 11 (2). Зеленые водоросли. Класс конъюгаты. Порядок Десмидиевые (2). - Ленинград: Советская наука, 1982. - 620 с.)

Patova E. N., Demina I. V. Algae of other divisions. Biodiversity of the Polar Ural ecosystems. - Syktyvkar, 2007. 252 p. (In Russian) (Патова Е. Н., Демина И. В. Водоросли других отделов. Биоразнообразие экосистем Полярного Урала. - Сыктывкар, 2007. - 252 с.)

Safonova T. A., Shaulo S. P. New and rare species of algae for the Western Siberia // Turczaninowia, 2006. - Vol. 9, № 3. - P. 102-108. (In Russian) (Сафонова Т. А., Шауло С. П. Новые и редкие виды водорослей для Западной Сибири // Turczaninowia, 2006. - Т. 9. №3. - С. 102-108.)

Safonova T. A., Shaulo S. P. The addition to algoflora of the water bodies of the middle taiga of the West Siberia // Turczaninowia, 2007. - Vol. 10, № 2. - P. 50-71. (In Russian) (Сафонова Т. А., Шауло С. П. Дополнение к альгофлоре водоемов средней тайги Западной Сибири // Turczaninowia, 2007. - Т. 10, № 2. - С. 50-71.)

Shakhmatov, A. S., Pavlovskiy, E. V. Diversity of desmid algae (Charophyta: Conjugatophyceae) in the vicinity of Yugorsk city (KMAO-Yugra, Russia) // Folia Cryptogamica Estonica, 2019. - Vol. 56. - P. 11-22.

Skorobogatova O. N., Naumenko Y. V. Genus Closterium Ehr. In the phytoplankton of the Vakh river (West Siberia) // Problems of Botany of South Siberia and Mongolia: Proceedings of 8th International Scientific-Practical Conference (Barnaul, 19-22 Oktober 2009). - Barnaul, 2009. - 480 p. (In Russian) (Скоробогатова О. Н., Науменко Ю. В. Род Closterium Ehr. в фитопланктоне р. Вах (Западная Сибирь) // Проблемы ботаники Южной Сибири и Монголии: материалы VIII Международной науч.-практ. конф. (Барнаул, 19-22 октября 2009). - Барнаул, 2009. - С. 103-105.)

Skorobogatova O. N. Taxonomic Composition of Phytoplankton in the Vakh River (Western Siberia) // IOP Conference Series: Earth and Environmental Science, 2018. - Vol. 138. - P. 1-19.

West W., West G. S. A Monograph of the British Desmidiaceae, Vol. I: Ray Society. - London, 1904. - 206 p. 